\title{
Pain self-efficacy questionnaire and its use in samples with different pain duration time
}

\author{
Questionário de autoeficácia relacionado à dor e seu uso em amostra com diferentes durações \\ de ocorrência de dor
}

Fernanda Salloume Sampaio Bonafé1, João Marôco², Juliana Alvares Duarte Bonini Campos³

DOI 10.5935/2595-0118.20180008

\section{ABSTRACT}

BACKGROUND AND OBJECTIVES: The pain self-efficacy questionnaire has been frequently used in several languages, but its use is limited to chronic pain. This study aimed to i) evaluate the properties of the pain self-efficacy questionnaire among Brazilians with different durations of pain occurrence; ii) present a new proposal for estimation of the overall self-efficacy belief score; and iii) compare such score among different pain duration time.

METHODS: A total of 1,155 adults (79.0\% women; $38.6 \pm 10.8$ years) participated, 337 had no pain, 386 reported pain for less than 3 months, 253 reported pain for more than 3 months with a recurrent pattern, and 179 reported continuous pain for more than 3 months. The confirmatory factor analysis was performed to check the pain self-efficacy questionnaire unifactorial model good-fit. The pain self-efficacy questionnaire invariance was tested in independent samples using multigroup analysis. We proposed the calculation of the self-efficacy belief score from the factor score obtained in the confirmatory factor analysis. The score was compared among groups (ANOVA, alpha=5\%).

RESULTS: After inserting four correlations between errors of items, the pain self-efficacy questionnaire model shows to be fit to the sample $(\mathrm{X} 2 / \mathrm{df}=7.059$; $\mathrm{CFI}=0.978$; $\mathrm{GFI}=0.964$; $\mathrm{RM}$ $\mathrm{SEA}=0.072$ ). The model was invariant between independent samples. Lower self-efficacy belief was found among participants with pain for less than three months $(\mathrm{p}<0.05)$. 1. Universidade de Araraquara, Faculdade de Odontologia, Araraquara, SP, Brasil.
2. Instituto Superior de Psicologia Aplicada, Lisboa, Portugal.
3. Universidade Estadual Paulista, Faculdade de Ciências Farmacêuticas de Araraquara, Ara-
raquara, SP, Brasil.

Submitted in August 29, 2017

Accepted for publication in January 22, 2018.

Conflict of interests: none - Sponsoring sources: The authors would like to thank the financial support provided by the São Paulo Research Foundation (FAPESP) and the Coordination for the Improvement of Higher Education Personnel (CAPES) in form of grants \#2014/00874-3; \#2014/17624-0; \#2014/23611-8; \#2015/23126-5, and the National Council for Scientific and Technological Development, Brazil (301611/2015-7).

Correspondence to:

Juliana A D B Campos

Departamento de Alimentos e Nutriçăo, Faculdade de Ciências Farmacêuticas de Araraquara, Universidade Estadual Paulista - UNESP

Rodovia Araraquara-Jaú, Km 01, Campos Ville

14800-903 Araraquara, São Paulo, Brasil.

E-mail: jucampos@fcfar.unesp.br

(C) Sociedade Brasileira para o Estudo da Dor
CONCLUSION: There is evidence of a relationship between the self-efficacy belief and the pain characteristics, where the presence of pain and length of time living with pain might be important factors in the study of the concepts involved in the perceptions of pain and self-efficacy.

Keywords: Pain, Pain measurement, Psychometrics, Scale, Self-efficacy, Validation.

\section{RESUMO}

JUSTIFICATIVA E OBJETIVOS: A utilização do questionário de autoeficácia relacionado à dor tem sido frequente, porém, limitada ao contexto da dor crônica. Os objetivos deste estudo foram: i) avaliar as propriedades psicométricas do questionário de autoeficácia relacionado à dor para amostra de indivíduos brasileiros com diferentes duraçóes da ocorrência de dor, ii) apresentar uma nova proposta de estimativa do escore global da crença de autoeficácia e iii) comparar esse escore entre grupos com diferentes duraçóes de dor.

MÉTODOS: Participaram 1.155 adultos (79,0\% mulheres; $38,6 \pm 10,8$ anos). Do total, 337 não apresentavam dor, 386 relataram dor há menos de 3 meses, 253 relataram dor recorrente há mais de 3 meses e 179, dor contínua há mais de 3 meses. Realizou-se análise fatorial confirmatória para verificar o ajustamento do modelo do Questionário de Autoeficácia relacionado à Dor. A invariância do questionário de autoeficácia relacionado à dor foi testada utilizando análise multigrupos. Foi proposto cômputo do escore global da crença de autoeficácia a partir da matriz dos pesos de regressão da análise fatorial confirmatória. $\mathrm{O}$ escore de autoeficácia foi comparado entre grupos (ANOVA, alfa=5\%).

RESULTADOS: Após inserção de quatro correlações entre os erros dos itens, o modelo do questionário de autoeficácia relacionado à dor apresentou ajustamento adequado à amostra (X2/gl=7,059; CFI=0,978; GFI=0,964; RMSEA=0,072). $\mathrm{O}$ modelo foi invariante entre as amostras independentes. Menor escore de crença de autoeficácia foi encontrado entre os participantes com dor presente há menos de 3 meses $(\mathrm{p}<0,05)$.

CONCLUSÃO: Há evidências da relação entre a crença de autoeficácia e as características da condição dolorosa, o que permite discussóes acerca das conceituaçóes teóricas envolvidas na percepçấo da dor e autoeficácia dos indivíduos.

Descritores: Autoeficácia, Dor, Escala, Mensuração da dor, Psicometria, Validação. 


\section{INTRODUCTION}

Self-efficacy can be defined as an individual's degree of belief/ trust to perform an activity or specific behavior required to achieve a goal/outcome, considering the effort being expended by the individual and his/her persistence in the face of obstacles/ aversive experiences ${ }^{1-3}$.

Nicholas ${ }^{2,4}$ identified chronic pain as one of such obstacles/aversive experiences, and proposed an instrument to assess the self-efficacy belief. The pain self-efficacy questionnaire (PSEQ) is composed of 10 items arranged in a unifactorial model and was developed to investigate the degree of trust that patients with chronic pain have on themselves to perform daily activities or functions.

The use of PSEQ has grown with the increase in translations and adaptations to different languages ${ }^{3,5-12}$. In spite of its wide use, few studies ${ }^{5,7,8,11}$ have shown evidence of the instrument's psychometric properties in different samples based on a confirmatory analysis of the psychometric properties.

As the PSEQ was developed to assess the self-efficacy belief in individuals with chronic pain, its use is still aimed mainly to this pain condition ${ }^{13}$. However, Rokke et al. ${ }^{14}$ pointed out the important role that the self-efficacy belief plays on other pain conditions such as, for example, acute pain tolerance. Thus, a space is open to the need for research and discussion of this concept in different contexts, such as acute pain and recurrent pain. The assessment of the self-efficacy belief can also be suggested with individuals without pain, aiming to carry out discussions that allow evaluating aspects of the operationalization and/or processing of the memorization of pain, which can also be relevant in the clinical context.

Originally, the strategy proposed to calculate the overall self-efficacy belief score was the sum of the responses provided by individuals to $10 \mathrm{PSEQ}^{2,4}$ items. From the sum, there is a minimum-maximum value that can be obtained, and it is considered that all items have the same weight in the operationalization of the construct being measured. However, validation studies have been pointing out that the sum can be a fragile strategy to calculate a construct's overall score, because during the refinement of the model to the different samples, it is possible to exclude items, which will inevitably compromise the points of reference adopted to calculate the overallscore ${ }^{15}$. Another aspect to be taken into consideration is that, when the sum is used, the same weight is assigned to each item to calculate the overall score, which is not realistic. Thus, in this work, we will present a new proposal to calculate the overall self-efficacy belief score based on the factor score weight obtained in the confirmatory factorial analysis. This strategy preserved the instrument's operationalization in the capture of the sample's construct; therefore, the resulting score is estimated with less error ${ }^{15-17}$.

Thus, this study aimed at assessing the psychometric properties of the PSEQ with a sample of Brazilian adults with different durations of pain occurrence; ii) proposing a new method to calculate the overall self-efficacy belief score; and iii) comparing the score among groups with different durations of pain.

\section{METHODS}

This is an observational study (with non-probability sampling by convenience) that relied on the participation of adults seeking dental care at the School of Dentistry of Araraquara (UNESP), in 2015 and 2016. The sample was composed only of individuals with ages 18 and above who agreed with and signed the Free Informed Consent Form (FICT). Individuals that sought assistance at the special patients' clinic were excluded.

The minimum sample size was estimated considering the proposal of Hair et al. ${ }^{18}$, who suggest the need of 5 to 10 subjects per model parameter. Considering that the factorial models to be tested for the PSEQ could have up to 20 parameters, it was verified that the estimated minimum sample size was from 100 to 200 subjects. Considering that this study also aimed at comparing individuals with different pain conditions (without pain, pain for less than 3 months, recurrent pain for more than 3 months, and continuous pain for more than 3 months), each group should have this sample size. Further, considering the likelihood of refusal to participate in the study, we have increased this estimate in 30\%, obtaining the result that at least 1,040 subjects should be invited to participate. Thus, 1,426 individuals were invited. Of these, 1,214 consented to participate and 1,155 answered all items of the PSEQ.

\section{Sample characterization}

For the sample characterization, we collected information such as gender, age, marital status, and economic level. The economic level was estimated by means of the Brazil Economic Classification Criteria ${ }^{19}$. Information related to the pain characteristics was also collected. Considering the proposal of the International Association for the Study of Pain (IASP) ${ }^{20,21}$ the information collected were presence/lack of pain (in the last 24 hours), pain onset and pattern of pain (crises/episodes or continuous). Such information helped in classifying participants into 4 groups. Individuals who did not have pain in the 24 hours before the study were included in group G0 (without pain). Individuals who reported pain in the 24 hours and the pain started within the 3 previous months were included in group G1 (pain $<3$ months). For individuals who reported pain beginning before the 3 previous months we considered the pattern of the pain (recurrent/continuous). Thus, individuals with recurrent pain for more than 3 months were included in G2 (recurrent pain $\geq 3$ months,), while individuals with continuous pain for more than 3 months were included in G3 (continuous pain $\geq 3$ months). Participants also reported the place of the worse pain (orofacial/body). Those who reported no pain in the last 24 hours before the interview also answered the questions "When was the last time you felt pain"?

The PSEQ was used is composed of 10 items distributed in a single factor called "Pain Self-Efficacy Belief". The options for the responses varied from zero (not confident at all) to 6 (completely confident). The reference period used for the response to the items of the instrument was the individual's general pain experience. The Portuguese version used was based on the proposal of Sardá et al. ${ }^{3}$. 
The PSEQ version proposed by Sardá et al. ${ }^{3}$ was analyzed in comparison with the instrument's original version ${ }^{2,4}$ by the study's researchers and a bilingual translator, independently. To that end, we have used the orthographic agreement established among Portuguese speaking countries in 2009. The word "posso" was changed to "consigo" at the beginning of each item of the instrument, and item 3 has undergone grammatical reconstruction to ensure its standardization in relation to the other items of the instrument. After these changes, the adapted Portuguese version of the PSEQ (Table 1) was tested by means of a Pilot Study.

The adapted Portuguese version of the PSEQ was applied to 25 adult patients ( $81 \%$ women) with average age of 45.73 $(\mathrm{SD}=10.41)$ years, seeking care at the School of Dentistry of Araraquara (FOAR-UNESP), Brazil. The average time to complete the PSEQ was 2.67 ( $\mathrm{SD}=0.97)$ minutes. To check the participants' understanding in relation to the terms/words of each item, we estimated the lack of understanding (II). All items were understood by all participants $(\mathrm{II}=0)$.

The content validity ratio (CVR) was carried out for the adapted Portuguese version, by adopting Lawshe ${ }^{22}$ proposal. In this phase, 8 pain/psychometrics experts participated, who classified each item of the PSEQ according to their essentiality into "essential", "useful, but not essential" and "not necessary". For the decision taking, the proposal of Wilson et al. ${ }^{23}$ was used considering a significance level of $5 \%\left(\mathrm{CVR}_{8 ; 0.05}=0.693\right)$.

\section{Analysis of psychometric properties}

Psychometric sensitivity

The psychometric sensitivity of the PSEQ items was evaluated using the measures of central tendency, variability and shape of the distribution of responses provided by the participants. The kurtosis $(\mathrm{Ku})<7$ and skewness $(\mathrm{Sk})<3$ absolute values were considered as indicators of psychometric sensitivity ${ }^{15,24}$.

\section{Construct validity}

The factorial and convergent validities were estimated to assess the construct validity.

Factorial validity

A confirmatory factorial analysis (CFA) was performed using the maximum likelihood estimation method. The chi-square ratio by degrees of freedom $\left(\chi^{2} / \mathrm{df}\right)$, the comparative fit index (CFI), the goodness of fit index (GFI), and the root mean square error of approximation (RMSEA) were used as goodness-of-fit indices of model ${ }^{15,24}$.

The model's fit was considered adequate when $\chi^{2} / \mathrm{df} \leq 2.00$, CFI and $\mathrm{GFI} \geq 0.90$, and $\mathrm{RMSE} A<0.10$. Items whose factorial loadings $(\lambda)$ were $<0.50$ were excluded. Correlations among items' errors were included when pointed out by the modification indices calculated from the method of Lagrange Multipliers $(\mathrm{LM}>11, \mathrm{p}<0.001)^{15}$.

\section{Convergent validity}

Convergent validity was assessed according to the proposal of Fornell and Larcker ${ }^{25}$, which recommend the estimation of the average variance extracted (AVE). AVE $\geq 0.50$ were deemed as adequate $^{15,18}$.
Reliability

The reliability was estimated by means of standardized Cronbach's alpha coefficient $(\alpha)$ and composite reliability (CR). Values of and $C R \geq 0.70$ indicated adequate reliability ${ }^{15,18}$.

\section{Factorial invariance}

The factorial invariance was carried out using the multigroup analysis with the Chi-square difference test $\left(\Delta \chi^{2}\right)^{15}$.

The factorial invariance of the model's parameters was estimated between independent samples to ascertain the result's external validity. To assess the factorial invariance in independent samples, the sample was divided in half; each subsample was called "Test Sample" ( $n=577)$ and "Validation Sample" ( $n=578)$. It should be clarified that such samples were randomly selected using the program IBM SPSS Statistics (v.22, SPSS an IBM Company, Chicago, IL). The invariance test was performed by the imposition of equality constraints to the models of both subsamples. The model presented metric invariance when the factorial loading were invariant $\left(\Delta \chi^{2} \lambda ; p \geq 0.05\right)$, which represents weak metric invariance. It was considered that the scalar invariance was present when the factorial loading and intercepts did not statistically differ between independent samples $\left(\Delta \chi^{2} \lambda\right.$ and $\left.\Delta \chi^{2} \mathrm{i} ; \mathrm{p} \geq 0.05\right)$, which represents strong metric invariance. When the factorial loading, intercepts and residual variances/covariances did not statistically differ between subsamples $\left(\Delta \chi^{2} \lambda, \Delta \chi^{2} \lambda\right.$ and $\Delta \chi^{2}$ Res; $\left.\mathrm{p} \geq 0.05\right)$, there was strict invariance. The external validity was considered adequate when at least strong metric invariance was observed.

Overall score

To calculate the overall score of the PSEQ factor, the regression weight matrix (W) obtained in the confirmatory factorial analysis was used, considering the covariance matrix between manifest (items) and the covariance matrix between latent (factor and errors) and manifest variables ${ }^{15}$. Thus, a weight was estimated for each item of the instrument. To keep the exact metric of the instrument's items, such weights were adjusted to the minimum-maximum of the response's options (zero to 6).

The overall self-efficacy belief score for each individual was obtained by multiplying the weight of each item by the response provided by the individual to that same item. At the end, all values were summed to obtain the overall weighted score.

Comparison between groups (Criterion Discriminant Validity) To compare the overall score of "Pain Self-Efficacy Belief" among groups with different pain conditions, the one-way ANOVA was performed. The data homocedasticity was evaluated by the Levene test. The Tukey post hoc test was used to multiple comparisons. The significance level adopted was 5\%.

Programs IBM SPSS Statistics (v.22, SPSS an IBM Company, Chicago, IL) and AMOS 22.0 (SPSS an IBM Company, Chicago, IL) were used to carried out the analysis of the study.

The data collection was carried out at the waiting room of the FOAR-UNESP clinics before the beginning of the care. Individuals were interviewed (face to face) individually. This study was approved by the Human Research Ethics Committee of the School of Dentistry of Araraquara (CAAE 14986014.0000.5416). 


\section{RESULTS}

The adapted Portuguese version of the PSEQ and the content validity ratio are presented in table 1 .

The study sample characteristics are presented in table 2 .

It should be noted that in all groups, most participants were women, married/in common-law marriage, with economic level C. There is a different prevalence of men and women in different groups. Most participants of group G1 reported orofacial pain as the worst pain, while group G3 reported body pain, this fact may be related to the place of data collection.

With regard to pain characteristics, individuals who reported no pain in the 24 hours have had their last pain $47.09(\mathrm{SD}=112.82)$ days before.

The descriptive statistics of responses provided by participants to the PSEQ items are found in table 3.

Table 1. Adapted Portuguese version and content validity ration of items of the pain self-efficacy questionnaire

\begin{tabular}{|c|c|c|c|c|}
\hline \multicolumn{2}{|c|}{ Face Validity } & \multirow[b]{2}{*}{$\begin{array}{l}\text { Adapted Portuguese Version }{ }^{\mathrm{b}} \\
\text { Pain self-efficacy questionnaire }\end{array}$} & \multicolumn{2}{|c|}{ Content validity } \\
\hline Item & $\begin{array}{l}\text { Original Version }{ }^{\mathrm{a}} \\
\text { Pain self-efficacy questionnaire }\end{array}$ & & $\begin{array}{l}\text { Essential } \\
\left(n^{c}\right)\end{array}$ & $\mathrm{CVR}^{\mathrm{d}}$ \\
\hline 1 & I can enjoy things, despite the pain. & Consigo apreciar/aproveitar as coisas, apesar da dor. & 8 & 1,00 \\
\hline 2 & $\begin{array}{l}\text { I can do most of the household chores (e.g., tidying- } \\
\text {-up, washing dishes, etc.), despite the pain. }\end{array}$ & $\begin{array}{l}\text { Consigo fazer a maior parte das tarefas domésticas (ex: La- } \\
\text { var a louça, arrumar a casa, lavar o carro....), apesar da dor. }\end{array}$ & 7 & 0,75 \\
\hline 3 & $\begin{array}{l}\text { I can socialize with my friends or family members as } \\
\text { often as I used to do, despite the pain. }\end{array}$ & $\begin{array}{l}\text { Consigo encontrar meus amigos e familiares com a mesma } \\
\text { frequência que antes, apesar da dor. }\end{array}$ & 8 & 1,00 \\
\hline 5 & $\begin{array}{l}\text { I can do some form of work, despite the pain. } \\
\text { ("work" includes housework, paid and unpaid work). }\end{array}$ & $\begin{array}{l}\text { Consigo fazer alguns trabalhos (ex: trabalhos de casa e em- } \\
\text { prego remunerado ou não), apesar da dor. }\end{array}$ & 8 & 1,00 \\
\hline 6 & $\begin{array}{l}\text { I can still do many of the things I enjoy doing, such } \\
\text { as hobbies or leisure activity, despite pain. }\end{array}$ & $\begin{array}{l}\text { Consigo fazer muitas coisas que aprecio (ex: lazer, artesa- } \\
\text { nato, esporte...) apesar da dor }\end{array}$ & 8 & 1,00 \\
\hline 7 & I can cope with my pain without medication. & Consigo lidar com a dor sem usar remédios. & 8 & 1,00 \\
\hline 10 & I can gradually become more active, despite the pain. & Consigo aos poucos me tornar mais ativo, apesar da dor. & 8 & 1,00 \\
\hline
\end{tabular}

Table 2. Sample characterization

\begin{tabular}{|c|c|c|c|c|c|}
\hline \multirow[b]{2}{*}{ Characteristics } & \multicolumn{5}{|c|}{ Groups* } \\
\hline & Go & G1 & G2 & G3 & Total \\
\hline $\mathrm{n}$ & 337 & 386 & 253 & 179 & 1,155 \\
\hline Age (mean, SD) & $38.15 \pm 10.75$ & $36.60 \pm 9.92$ & $38.06 \pm 11.09$ & $44.67 \pm 10.20$ & $38.62 \pm 10.79$ \\
\hline \multicolumn{6}{|l|}{ Gender } \\
\hline Male & 84 & 105 & 32 & 21 & 242 \\
\hline Female & 253 & 281 & 221 & 158 & 913 \\
\hline \multicolumn{6}{|l|}{ Marital status } \\
\hline Single & 101 & 141 & 64 & 31 & 337 \\
\hline Married/common-law marriage & 197 & 203 & 158 & 111 & 669 \\
\hline Widow & 10 & 8 & 9 & 7 & 34 \\
\hline Divorced & 29 & 34 & 22 & 30 & 115 \\
\hline \multicolumn{6}{|l|}{ Economic level } \\
\hline$A / B$ & 146 & 131 & 94 & 57 & 428 \\
\hline $\mathrm{C}$ & 171 & 218 & 129 & 107 & 625 \\
\hline $\mathrm{D} / \mathrm{E}$ & 20 & 37 & 30 & 15 & 102 \\
\hline \multicolumn{6}{|l|}{ Place of the worst pain } \\
\hline Orofacial & 170 & 320 & 121 & 34 & 645 \\
\hline Body & 167 & 66 & 132 & 145 & 510 \\
\hline
\end{tabular}

${ }^{\star} \mathrm{G} 0$ (without pain), G1 (pain $<3$ months), G2 (pain $\geq 3$ months, recurrent), G3 (pain $\geq 3$ months, continuous). 
Table 3. Descriptive statistics (mean, standard-deviation, kurtosis and skewness) of responses provided by participants to items of the pain self-efficacy questionnaire for the different groups

\begin{tabular}{lccccc}
\hline \multicolumn{7}{c}{ Item } & \multicolumn{5}{c}{ Mean(standard-deviation)/kurtosis/skewness } & Groups & Gotal \\
\hline 1 & $3.93(1.68) /-0.10 /-0.70$ & $3.19(1.89) /-0.87 /-0.32$ & $3.67(1.73) /-0.43 /-0.54$ & $3.73(1.88) /-0.51 /-0.68$ & $3.59(1.82) /-0.56 /-0.54$ \\
2 & $4.13(1.66) / 0.10 /-0.85$ & $3.50(1.89) /-0.85 /-0.43$ & $3.92(1.80) /-0.48 /-0.69$ & $3.89(1.89) /-0.41 /-0.79$ & $3.84(1.82) /-0.50 /-0.66$ \\
3 & $3.82(1.91) /-0.66 /-0.61$ & $2.92(2.13) /-1.37 /-0.09$ & $3.38(1.97) /-1.09 /-0.29$ & $3.34(2.14) /-1.18 /-0.40$ & $3.35(2.06) /-1.15 /-0.34$ \\
4 & $4.13(1.62) /-0.11 /-0.72$ & $3.42(1.94) /-0.88 /-0.49$ & $3.78(1.73) /-0.42 /-0.63$ & $3.92(1.80) /-0.18 /-0.80$ & $3.78(1.80) /-0.45 /-0.66$ \\
5 & $4.20(1.65) / 0.15 /-0.90$ & $3.66(1.84) /-0.55 /-0.66$ & $4.11(1.58) /-0.14 /-0.74$ & $3.99(1.88) /-0.29 /-0.83$ & $3.97(1.75) /-0.21 /-0.79$ \\
6 & $3.55(2.01) /-0.94 /-0.51$ & $2.66(2.09) /-1.35 / 0.02$ & $3.28(2.09) /-1.18 /-0.31$ & $2.87(2.32) /-1.54 /-0.05$ & $3.09(2.13) /-1.30 /-0.22$ \\
7 & $2.53(2.05) /-1.28 / 0.12$ & $1.84(2.12) /-1.08 / 0.66$ & $1.97(2.12) /-1.12 / 0.58$ & $2.01(2.17) /-1.19 / 0.53$ & $2.09(2.12) /-1.24 / 0.45$ \\
8 & $4.04(1.72) / 0.03 /-0.87$ & $3.32(1.97) /-0.95 /-0.42$ & $3.78(1.92) /-0.56 /-0.70$ & $3.45(2.00) /-0.86 /-0.50$ & $3.65(1.92) /-0.65 /-0.62$ \\
9 & $4.09(1.76) /-0.07 /-0.88$ & $3.19(2.15) /-1.28 /-0.33$ & $3.82(1.87) /-0.51 /-0.68$ & $3.66(1.99) /-0.64 /-0.70$ & $3.66(1.99) /-0.77 /-0.63$ \\
10 & $3.93(1.80) /-0.24 /-0.82$ & $3.12(2.09) /-1.23 /-0.30$ & $3.62(1.84) /-0.59 /-0.58$ & $3.40(2.01) /-0.87 /-0.54$ & $3.51(1.97) /-0.84 /-0.55$ \\
\hline
\end{tabular}

${ }^{*} \mathrm{G} 0$ (without pain), G1 (pain <3months), G2 (pain $\geq 3$ months, recurrent), G3 (pain $\geq 3$ months, continuous).

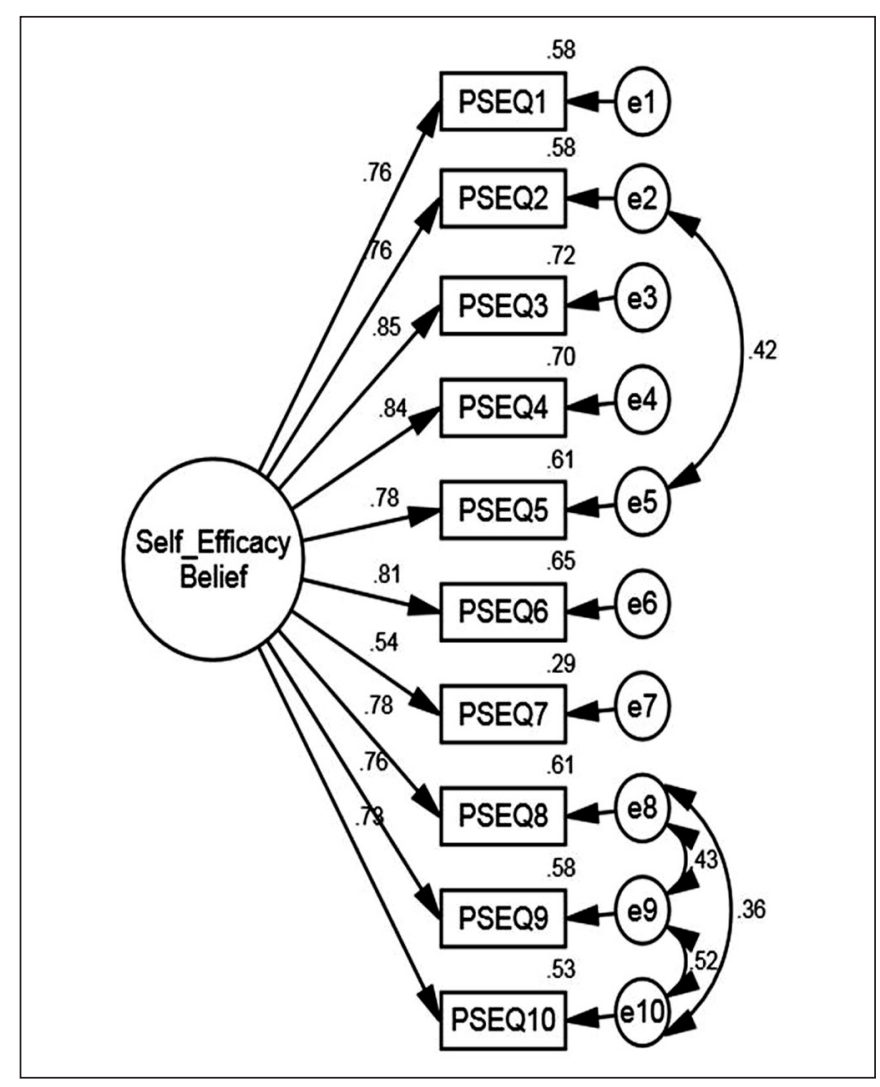

Figure 1. Refined model (MR) of the pain self-efficacy questionnaire for the sample

This model also presented adequate fit for the different pain conditions (G0: $\chi^{2} / \mathrm{df}=3.324 ; \mathrm{CFI}=0.972 ; \mathrm{GFI}=0.942 ; \mathrm{RMSEA}=0.083 ; \mathrm{G} 1: \chi^{2} / \mathrm{df}=4.318$; $\mathrm{CFI}=0.962 ; \mathrm{GFI}=0.936 ; \mathrm{RMSEA}=0.090 ; \mathrm{G} 2: \chi^{2} / \mathrm{df}=1.711 ; \mathrm{CFI}=0.989 ; \mathrm{GFI}=0.959 ;$ RMSEA=0.053; and G3: $\chi^{2} / \mathrm{df}=2.435 ; \mathrm{CFI}=0.964 ; \mathrm{GFI}=0.928 ; \mathrm{RMSEA}=0.090$ ). This model presented strict invariance in independent samples (Test Sample vs Validation Sample: $\Delta \chi^{2} \lambda(10)=2.574 ; p=0.990 ; \Delta \chi^{2} i(10)=16.507$; $\left.\mathrm{p}=0.086 ; \Delta \chi^{2} \operatorname{Res}(14)=14.737 ; \mathrm{p}=0.396\right)$.

Equation 1 presents the weights of each item for the calculation of the overall score of self-efficacy belief for the sample, considering the minimum-maximum value from 0 to 6 .

Self-Efficacy Belief $=0.12 \mathrm{PSEQ} 1+0.08 \mathrm{PSEQ} 2+0.17 \mathrm{PSEQ} 3+0.19 \mathrm{PSEQ} 4$ $+0.10 \mathrm{PSEQ} 5+0.13 \mathrm{PSEQ} 6+0.04 \mathrm{PSEQ} 7+0.08 \mathrm{PSEQ} 8+0.05 \mathrm{PSEQ} 9+$ 0.04PSEQ10 (1)
All items of the PSEQ had adequate psychometric sensitivity in all groups; therefore, there was no severe violation of the normality of the distribution of responses. However, it should be highlighted that the individuals' responses to item 7 had a different pattern from the remaining items, being below the scale's mean point.

The unifactorial model of the PSEQ did not present adequate fit to the sample $\left(\lambda=0.54-0.83 ; \chi^{2} / \mathrm{df}=25.575 ; \mathrm{CFI}=0.900\right.$; GFI=0.848; RMSEA=0.146; AVE=0.60; $\mathrm{CR}=0.94 ; \alpha=0.93$ ).

The modification indices pointed out the existence of correlations between items' errors 2-5 (LM=224.490), 8-9 ( $\mathrm{LM}=118.953)$, 8-10 (LM=67.088) and 9-10 (LM=230.740). After inclusion of these correlations, the model presented adequate fit to the sample $\left(\lambda=0.54-0.85 ; \Delta \chi^{2} / \mathrm{df}=7.059 ; \mathrm{CFI}=0.978 ; \mathrm{GFI}=0.964\right.$; RMSEA $=0.072)$ and was called refined model $\left(M_{R}\right)$. The model also presented adequate convergent validity $(\mathrm{AVE}=0.59)$ and reliability $(\mathrm{CR}=0.93 ; \alpha=0.93)$.

Figure 1 shows the structure and factorial loadings of the $M_{R}$ for the sample.

The comparison of the self-efficacy belief score among groups with different pain conditions is found in table 4. ANOVA shows that the self-efficacy belief significantly differs among the different groups, showing the validity of the scale's criterion to differentiate groups of patients with different pain conditions.

Table 4. Comparison of means \pm standard-deviation of overall $p$ self-efficacy belief scores among groups with different pain conditions

\begin{tabular}{lcc}
\hline Groups $^{*}$ & $\begin{array}{c}\text { Self-efficacy belief } \\
\text { (mean } \pm \text { standard deviation) }\end{array}$ & ANOVA \\
\hline G0 & $3.89 \pm 1.47^{\mathrm{a}}$ & $\mathrm{F}=14.663 ; \mathrm{p}<0.001$ \\
G1 & $3.13 \pm 1.60^{\mathrm{b}}$ & \\
G2 & $3.59 \pm 1.54^{\mathrm{a} . \mathrm{c}}$ & \\
G3 & $3.50 \pm 1.61^{\mathrm{c}}$ & \\
Total & $3.51 \pm 1.58$ & \\
\hline
\end{tabular}

${ }^{*} \mathrm{G0}$ (without pain), G1 (pain <3months), G2 (pain $\geq 3$ months, recurrent), G3 (pain $\geq 3$ months, continuous); a,bdifferent letters indicate significant statistical difference. Tukey post hoc test $(\alpha=5 \%)$.

Individuals who reported pain with duration of less than 3 months believe to have less self-efficacy in relation to pain than the other individuals. 


\section{DISCUSSION}

This study aimed to contribute with the expansion of the investigations of self-efficacy in different pain contexts beyond chronic pain. For the first time, evidence of the validity, reliability and invariance of the PSEQ for a Brazilian sample with different pain conditions was presented in the literature. Furthermore, this study brings a new proposal to estimate the overall score of the "Pain Self-Efficacy Belief" to minimize errors of the measurement obtained with the PSEQ.

The PSEQ unifactorial model ${ }^{2,4}$, was confirmed in this Brazilian sample composed of individuals with different pain conditions. For adequate fit, the model was refined with the inclusion of correlations between items' errors (2-5, 8-9, 8-10, and 9-10). Such correlations were included due to the theoretical approach among these items. Items 2 and 5 address issues regarding work-related everyday activities, either developed at home (item 2: household chores) or any other activity (item 5: work at home or paid employment). Items 8,9 and 10 somehow complement each other by carrying concepts related to abstract situations of life such as the achievement of life goals (item 8), becoming more active (item 10), and living a normal lifestyle (item 9). It should be emphasized that, in addition to presenting adequate validity and reliability, this new structure also presented adequate invariance with independent samples, which points out to the adequate external validity of the results presented.

Further, in relation to the items of this instrument, we should refer to our observation of the response pattern of item 7 (Table 3). Most items usually point out a beliefs level to carry out daily activities/chores higher than the scale's mean point; item 7 points out the individuals' lower beliefs level when dealing with pain without using medicines. In view of a similar result, Di Pietro et al. ${ }^{10}$ and Chiarotto et al. ${ }^{11}$ proposed that this item could present a high potential to differentiate the individuals' behaviors when facing pain, as it approaches the self-efficacy belief in dealing with pain using no medicines. Thus, this item could have clinical aggregate value in the assessment of pain-related self-efficacy.

Although assessments of self-efficacy are widely carried out, such assessments are often made with samples of individuals with chronic pain ${ }^{13}$. To the extent of our knowledge, this is the first study that proposed evaluating the psychometric properties of the PSEQ model in a sample of individuals with other pain profiles. Thus, new possibilities are opened to investigate this construct. Among such possibilities, we can mention the influence and importance of self-efficacy in the handling and success of the treatment of patients with different types of pain or, in another perspective, the influence of pain characteristics in pain self-efficacy belief. It is speculated, from the comparison of the self-efficacy belief scores between groups with different pain conditions, that the characteristics of the pain can be relevant. Table 4 shows that the self-efficacy belief was lower in group G1, which can indicate that the individual's reaction/behavior when facing a recent event can be different from his/her reaction after living with the pain, believing that the time of living with a certain condition, summed to the individual cognitive-behavioral tools and/or strategies could result in the increase of the belief on one's capacity to organize and perform the necessary behaviors to reach objectives and resist when facing obstacles and difficulties. For this reason, when facing recent event (pain for less than 3 months: G1) the individual might present lower self-efficacy belief score than when facing an already-known pain (G2 and G3), or in view only of a memory of pain (G0). However, it should be noted that this study has a limitation related to the interpretation of cause and effect results due to the study design adopted. It is expected that longitudinal studies be carried out to prove this suggestion.

The calculation of the overall self-efficacy belief score, it should be emphasized that, from the use of the confirmatory factorial analysis, it is possible to estimate a measure more adequate to the sample, complying with the implicit characteristics of the operationalization of the PSEQ ${ }^{15-17}$. Thus, the proposal to calculate the overall weighted score (Equation 1) allows estimating the pain self-efficacy belief score in a more accurate manner. It should be noted, however, that the values presented are estimates for a sample representing a certain population; therefore, it is not necessarily reproducible with other samples with different characteristics ${ }^{15,26}$. Others limitations and proposals for future studies can be listed. It should be noted that, although this study has presented a Portuguese version of the PSEQ, adapted in accordance with the orthographic agreement among Brazil and other Portuguese-speaking countries, this version was not tested abroad. Thus, we suggest that future studies be carried out to evaluate the possibility of using a single Portuguese version in different Portuguese-speaking countries (transnational validation). It is further expected that other studies consider this method to investigate the psychometric properties, invariance of the PSEQ model's parameters, and the estimates of the Pain Self-Efficacy Belief factor in samples representing other populations, so that discussions regarding the operationalization of the construct self-efficacy belief are encouraged. Furthermore, it is expected that further studies take into account the relation between self-efficacy belief and the presence/lack of pain and the pain characteristics, so that new evidence is presented that might bring about new discussions about the theoretical concepts involved in the perception of pain and self-efficacy.

\section{CONCLUSION}

It is concluded that the PSEQ was valid and reliable for the sample of Brazilian adults with different pain conditions. Thus, the possibility of extending the use of this instrument to clinical and/or epidemiological contexts that go beyond the chronic pain should be considered. In addition, there is evidence of a relationship between the self-efficacy belief and the pain characteristics, where the presence of pain and length of time living with pain might be important factors in the study of the concepts involved in the perceptions of pain and self-efficacy.

\section{ACKNOWLEDGEMENT}

The authors would like to thank psychologist Fernanda Cristina Maurício for her collaboration in data collection. 


\section{REFERENCES}

1. Bandura A. Self-efficacy: toward a unifying theory of behavioral change. Psychol Rev. 1977;84(2):191-215.

2. Nicholas MK. The pain self-efficacy questionnaire: taking pain into account. Eur J Pain. 2007;11(2):153-63.

3. Sardá J, Nicholas MK, Pimenta CA, Asgharl A. Pain-related self-efficacy beliefs in a Brazilian chronic pain patient sample: a psychometric analysis. Stress Health. 2007;23(3):185-90

4. Nicholas MK. Self-efficacy and chronic pain. Paper presented at the annual conference of the British Psychological Society; 1989.

5. Asghari A, Nicholas MK. An investigation of pain self-efficacy beliefs in Iranian chronic pain patients: a preliminary validation of a translated English-language scale. Pain Med. 2009;10(4):619-32.

6. Vong SK, Cheing GL, Chan CC, Chan F, Leung AS. Measurement structure of the Pain Self-Efficacy Questionnaire in a sample of Chinese patients with chronic pain. Clin Rehabil. 2009;23(11):1034-43.

7. Ferreira-Valente MA, Pais-Ribeiro JL, Jensen MP. Psychometric properties of the Portuguese version of the Pain Self-Efficacy Questionnaire. Acta Reumatol Port. 2011;36(3):260-7.

8. van der Maas LC, de Vet HC, Koke A, Bosscher RJ, Peters ML. Psychometric properties of the Pain Self-Efficacy Questionnaire (PSEQ) validation, prediction, and discrimination quality of the Dutch version. Eur J Psycholog Assess. 2012;28(1):68-75.

9. Adachi T, Nakae A, Maruo T, Shi K, Shibata M, Maeda L, et al. Validation of the Japanese version of the pain self-efficacy questionnaire in Japanese patients with chronic pain. Pain Med. 2014;15(8):1405-17.

10. Di Pietro F, Catley MJ, McAuley JH, Parkitny L, Maher CG, Costa Lda C, et al. Rasch analysis supports the use of the Pain Self-Efficacy Questionnaire. Phys Ther. 2014;94(1):91-100.

11. Chiarotto A, Vanti C, Ostelo RW, Ferrari S, Tedesco G, Rocca B, et al. The Pain Self-Efficacy Questionnaire: cross-cultural adaptation into Italian and assessment of Its measurement properties. Pain Pract. 2015;15(8):738-47.
12. Rasmussen MU, Rydahl-Hansen S, Amris K, Samsøe BD, Mortensen EL. The adaptation of a Danish version of the Pain Self-Efficacy Questionnaire: reliability and construct validity in a population of patients with fibromyalgia in Denmark. Scand J Caring Sci. 2016;30(1):202-10.

13. Jackson T, Wang Y, Wang Y, Fan H. Self-efficacy and chronic pain outcomes: a meta-analytic review. J Pain. 2014;15(8):800-14

14. Rokke PD, Fleming-Ficek S, Siemens NM, Hegstad HJ. Self-efficacy and choice of coping strategies for tolerating acute pain. J Behav Med. 2004;27(4):343-60.

15. Maroco J. Análise de equaçốes estruturais: fundamentos teóricos, software \& aplicaçốes. Pero Pinheiro: ReportNumber; 2014. 374p.

16. da Silva WR, Marôco J, Ochner CN, Campos JA. Male body dissatisfaction scale (MBDS): proposal for a reduced model. Eat Weight Disord. 2017;22(3):515-25.

17. Campos JA, Zucoloto ML, Bonafe FS, Maroco J. General oral health assessment index: a new evaluation proposal. Gerodontology. 2017;34(3):334-42.

18. Hair JF, Black WC, Babin B, Anderson RE, Tatham RL. Multivariate data analysis. $6^{\text {th }}$ ed. Prentice Hall; 2005. 928p.

19. ABEP. Associação Brasileira de Empresas de Pesquisa. Critério de Classificação Econômica Brasil. 2015 [21 janeiro 2016]; Available from: http://www.abep.org/new/ criterioBrasil.aspx.

20. International Association for the Study of Pain (IASP). Classification of chronic pain: description of chronic pain syndromes and definitions of pain terms. Seattle: IASP Press; 1994.

21. International Association for the Study of Pain (IASP). Pain terms: a list with definitions and notes on usage. Pain. 1979;6(3):249-52.

22. Lawshe CH. Quantitative approach to content validity. Pers Psychol. 1975;28(4):563-75.

23. Wilson FR, Pan W, Schumsky DA. recalculation of the critical values for lawshe's content validity ratio. Measurement and evaluation in counseling and development. 2012;45(3):197-210.

24. Kline RB. Principles and practice of structural equation modeling. New York: The Guilford Press; 1998. 354p.

25. Fornell C, Larcker DF. Evaluating Structural Equation Models with Unobservable Variables and Measurement Error. J Marketing Res. 1981;18(1):39-50.

26. Anastasi A. Psychological testing. Ed T. (editor). New York City: Macmillan; 1988. 